\title{
DEVELOPING A LOCAL INSTRUCTION THEORY FOR LEARNING COMBINATIONS
}

\author{
Ika Meika ${ }^{* 1}$, Didi Suryadi ${ }^{2}$, Darhim $^{3}$ \\ ${ }^{1}$ Universitas Mathla'ul Anwar Banten \\ ${ }^{2,3}$ Universtas Pendidikan Indonesia
}

\begin{tabular}{l} 
Article Info \\
Article history: \\
Received July 9, 2018 \\
Revised August 29, 2019 \\
Accepted Sept 2, 2019 \\
\hline Keywords: \\
Combinations, \\
HLT, \\
Local Instruction Theory, \\
RME
\end{tabular}

\begin{abstract}
This research aims at developing local instruction theory for learning combinations by using Realistic Mathematic Education (RME). The LIT flow developed in this study is to find an easy learning path to help students build basic concepts in combination material. To achieve the objectives of this study, researchers used design research. The Hypothetical Learning Trajectory (HLT) was developed from a series of activities to get a better understanding about combinations at Senior High School (SHS) students. Theoretical development is supported by interactive process in designing learning activities, conducting teaching experiment and conducting retrospective analysis to contribute to the development of LIT combinations. An understanding of combinations emerges and develops during classroom learning activities. Qualitative analysis of teaching experiments shows that by using LIT teaching materials that contain the characteristics of PMR, students can build basic concepts and develop their understanding about combination.
\end{abstract}

Copyright (c) 2019 IKIP Siliwangi. All rights reserved.

\section{Corresponding Author:}

Ika Meika,

Departement of Mathematics Education,

Universitas Mathla'ul Anwar Banten,

Jl. Raya Labuan KM 23, Saketi, Pandeglang, Banten 42273, Indonesia

Email: ikameika@unmabanten.co.id

\section{How to Cite:}

Meika, I., Suryadi, D., \& Darhim, D. (2019). Developing a local instruction theory for learning combinations. Infinity, 8(2), 157-166.

\section{INTRODUCTION}

Permutations and combinations are the basic materials in studying probability. Probability is part of mathematics that needs to be mastered by high school students as a prerequisite of statistical material that is very widely used in designing research and processing data of research results from various branches of science (Azhar \& Kusumah, 2011). Garfield \& Ahlgren (1988) revealed that permutations and combinations are the important parts of introduction to statistics at some universities. According to Van de Walle (2008) students' ideas about probability must evolve from experience (exploration). Further, Busadee \& Laosinchai (2013) stated that in studying permutations and combinations, students need real relevant issues to stimulate their learning and knowledge.

Not a few students are mistaken in solving combinatorics problems, especially on sub-topic of permutations and combinations. A common mistake is when using 
permutations and combinations in problem solving, if there is no instruction to use permutations and combinations in a question clearly, most likely students experience confusion. Garfield \& Ahlgren (1988) stated that the combination material is difficult material for students and is a prerequisite material for studying probability and statistics. The difficulty of high school students in learning permutations and combinations is an important issue in probability lessons (Ben-Hur, 2006; Busadee \& Laosinchai, 2013; Fischbein, 1975). Based on the results of preliminary research done by the authors showed that the error rate of students in solving the problem of combinatorics was quite high (Meika \& Suryadi, 2018).

Combinartorics is considered one of the more difficult mathematical topics to teach and to learn (Eizenberg \& Zaslavsky, 2004). One of the factors which causes difficulties in combinatoric learning is learning aid. Learning aids that have been widely used by students in schools have not been able to assist them in rediscovering mathematical concepts, and according to Fitria (2013) less optimal use of text book which supports teaching and learning process. In learning activities teacher usually explains the concept informatively, gives examples of problems, and provides exercises (Herman, 2007). Other problems which often occur is because most teachers are difficult to apply learning methods and teaching materials in accordance to lesson plan they have made (Yulianti, Zulkardi, \& Ilma, 2014). In order to make learning process runs optimally, teacher creativity is needed in the selection and use of appropriate learning resources with the development and needs of students, in this study we want to develop a special resource description on sub topic of the combination by using RME approach.

The RME learning approach is one of the learning approaches that involves the active students who present student contributions both in constructing knowledge as well as in interaction with the learning environment. While Local Instruction Theory (LIT) is a special theory that can guide and help someone learn particular topic, in this case the topic studied is a combination. LIT, Gravemeijer (1999, 2004), developed in the context of design research, shows the means of teacher reference framework to design and involve students in a set of learning stages, learning activities are examples that support the development of student math focused on concepts. LIT developed here contains characteristics of RME which uses real-life context, uses the model, there is students' contribution, interaction and interrelationships among topics.

\section{METHOD}

This research uses design research method. The core of design research are cyclic process from the activities of designing or testing a series of learning activities and other aspects of designing. Freudenthal (1991) mentioned that cyclic process in design research consists of idea/thought experiment and instruction experiment. Gravemeijer \& Cobb (2006) stated that there are 3 stages in the implementation of design research, namely: (1) Preparing for the Experiment. This preliminary design serves to implement the initial ideas gained from the literature review before designing the learning activities; (2) Teaching Experiment. This stage aims to collect data to be used to answer the research questions. A series of instructional activities that have been designed, tested and revised, are applied in the classroom. Research subjects in the teaching experiment were 19 students from the eleventh Natural Science-major graders at SMAN 1 Pandeglang, Banten; (3) Retrospective Analysis. The researcher analyzed the data obtained of the teaching experiment and used the results of the analysis to develop the next design. 


\section{RESULTS AND DISCUSSION}

The results presented include the stage of preparing for the experiment, teaching experiment, and retrospective analysis.

\subsection{Preparing for the Experiment}

In preliminary stage, preparation and completion of teaching materials were done. Activities undertaken at the preparatory stage: (1) analyzed the students by determining the research subjects of eleventh Natural Science-major graders at SMAN 4 Pandeglang with cognitive level of heterogeneous students (2) analyzed the curriculum to find out that the combination material is in line with the 2013 curriculum and (3) analyzed the material to know that basic competence "describe and apply various combination rules through several real examples and present the flow of formulation of combinations through diagrams or other means" is appropriate to the research objective. Then the researcher designed instructional materials in the form of Material Description or "Uraian Bahan Ajar Local Instruction Theory" (UBA-LIT) using Realistic Mathematics Education approach and learning aids including syllabus, Lesson Plan or (RPP), and assessment instruments developed in accordance with RME characteristics and 2013 curriculum. Furthermore, the learning aids that had been made were evaluated by the researcher. The result of selfevaluation is called first prototype. Expert reviews were then performed where the first prototype was validated by four experts based on content, constructs and language.

As the expert reviews stage was done, the first prototype was tested to five students who had received a combination lesson to check readability and work on teaching materials. Researchers interacted with students to see the difficulties which might occur during the use of UBA-LIT to provide input or correction if anything needs to be fixed. After it was tested, the researcher asked the students to comment freely on commentary sheet that had been provided. The student comments including UBA-LIT was very helpful in finding the concept of formal combination without memorizing the formula. There were several less understandable words which gave various meaning. Based on the validity test by the experts and the comments from the students it could be concluded that the first prototype teaching material product design developed was valid and had been revised into a second prototype based on the suggestions given. Furthermore, the second prototype was tested (teaching experiment 1) to the students of eleventh Natural Science-major graders at SMAN Cahaya Madani Banten Boarding School consisting of 19 pupils. Students were asked to solve problems on the teaching materials together in their group discussion to see the difficulties during the work and to simulate gradually the processing time.

In the perspective of design research, the purpose of the initial design is to formulate LIT that can be described and perfected during teaching experiment (Gravemeijer \& Cobb, 2006). During this literature study, we also began designing learning activities. The sequence of this learning activity includes the conjectures of students' thought and strategies developed and presented as the initial HLT. The HLT thought is dynamic and can be changed and adapted to the actual student learning process during the teaching experiment. HLT is a vehicle for planning student learning about the concept of combinatorics. The HLT component consists of learning objectives, description of activity, and conjectures of students' thoughts will be explained in each learning activity. HLT during the teaching experiment serves as a guideline for teachers and researchers to determine the focus of teaching, interviewing, and observing. HLT is also used as a guideline and reference point in analyzing the entire data set collected during the teaching experiment. HLT in teaching experiments is described in Table 1. 
Meika, Suryadi, \& Darhim, Developing a local instruction theory ...

Table 1. Overview of the HLT for learning the concept of combinations

\begin{tabular}{|c|c|c|c|}
\hline Activity & Main Goals & Description of Activity & $\begin{array}{c}\begin{array}{c}\text { Conjectures of students' } \\
\text { thought }\end{array} \\
\end{array}$ \\
\hline $\begin{array}{l}\text { Demonstrating } \\
\text { calculation in } \\
\text { handshake } \\
\text { (Visual Field } \\
\text { Activities) }\end{array}$ & $\begin{array}{l}\text { Students are } \\
\text { able to form a } \\
\text { combination } \\
\text { of } \\
\text { problematic } \\
\text { situations. }\end{array}$ & $\begin{array}{l}\text { - Teacher asks five } \\
\text { students to } \\
\text { demonstrate } \\
\text { handshake one } \\
\text { another, other } \\
\text { students notice and } \\
\text { understand the } \\
\text { handshake between } \\
\text { A and B which is } \\
\text { equal to handshake } \\
\text { from B to A. } \\
\text { - Each group notices } \\
\text { the demonstration } \\
\text { carefully, and } \\
\text { discusses how many } \\
\text { handshakes occur } \\
\text { from } 2 \text { people, } 3 \\
\text { people, } 4 \text { people, } 5 \\
\text { people and } n \text { people. }\end{array}$ & $\begin{array}{l}\text { - Some students may quickly } \\
\text { understand that the AB } \\
\text { sequence is same as BA } \\
\text { - Some students may be able } \\
\text { to conclude quickly the } \\
\text { number of handshakes that } \\
\text { occur. } \\
\text { - Some students may be able } \\
\text { to visualize this activity } \\
\text { and start building models } \\
\text { from many handshakes } \\
\text { from } 5 \text { people to } n \text { people. }\end{array}$ \\
\hline $\begin{array}{l}\text { Making color } \\
\text { mixtures }\end{array}$ & $\begin{array}{l}\text { Students are } \\
\text { able to find } \\
\text { understanding } \\
\text { and formula } \\
\text { of } \\
\text { combinations. }\end{array}$ & $\begin{array}{l}\text { Teacher asks students to } \\
\text { make color mixtures } \\
\text { using tree diagrams, } \\
\text { tables and list of } \\
\text { patterns, with guided } \\
\text { reinvention: } \\
-2 \text { of } 3 \text { colors provided } \\
-3 \text { of } 4 \text { colors provided } \\
-2 \text { of } 4 \text { colors provided } \\
-2 \text { of } 5 \text { colors provided } \\
-r \text { of } n \text { colors provided }\end{array}$ & $\begin{array}{l}\text { - Some students may use } \\
\text { tree diagrams to solve } \\
\text { them. } \\
\text { - Some students may quickly } \\
\text { find the number of color } \\
\text { mixtures by using tables. } \\
\text { - Some students may quickly } \\
\text { find the number of color } \\
\text { mixtures by listing } \\
\text { patterns. } \\
\text { - Some students may be able } \\
\text { to visualize this activity } \\
\text { and begin to build their } \\
\text { models and do horizontal } \\
\text { and vertical } \\
\text { mathematization to find the } \\
\text { multitude of color mixtures } \\
\text { from } r \text { color of } n \text { colors } \\
\text { provided. } \\
\text { - Some students may be able } \\
\text { to relate the association of } \\
\text { the color mixtures process } \\
\text { with the combination } \\
\text { concept. }\end{array}$ \\
\hline
\end{tabular}




\begin{tabular}{|c|c|c|c|}
\hline Activity & Main Goals & Description of Activity & $\begin{array}{c}\text { Conjectures of students' } \\
\text { thought }\end{array}$ \\
\hline $\begin{array}{l}\text { Resolving the } \\
\text { problem in a } \\
\text { story form }\end{array}$ & $\begin{array}{l}\text { Students are } \\
\text { able to } \\
\text { calculate } \\
\text { combinations } \\
\text { of } r \text { element } \\
\text { from different } \\
n \text { element and } \\
\text { solve } \\
\text { problems in } \\
\text { everyday life. }\end{array}$ & $\begin{array}{l}\text { Do the calculations to } \\
\text { find the combination } \\
\text { formula of } r \text { elements } \\
\text { from different } n \\
\text { elements }\end{array}$ & $\begin{array}{l}\text { - Some students may be able } \\
\text { to see the connection } \\
\text { between } n \text { ! with ( } n \text { - } r) \text { ! or } r \text { ! } \\
\text { in calculations and able to } \\
\text { simplify the calculations } \\
\text { - Some students may be able } \\
\text { to associate prior activity } \\
\text { for problem solving in this } \\
\text { activity. } \\
\text { - Some students may } \\
\text { accomplish it with tree } \\
\text { diagram / table / pattern } \\
\text { list. } \\
\text { - Some students may directly } \\
\text { use the combination } \\
\text { formula of } r \text { elements from } \\
\text { different } n \text { elements }\end{array}$ \\
\hline
\end{tabular}

\subsection{Teaching Experiment}

According to Gravemeijer \& Cobb (2006), the purpose of teaching experiment is to test and improve the conjecture LIT developed in the preliminary phase, and to develop an understanding of how it works. Teaching experiment also aims to collect data to answer research questions.

\section{Activity 1}

In this activity the teacher initiated learning by asking four students (volunteers) to perform handshakes among them. Let call these four students A, B, C, and D, shake hands each other once. The description of activities and parts of the LIT groove developed in this activity are presented in Figure 1.

Other students noticed their friends' handshake demonstrations in front of class, and calculated the number of different handshakes of four model students. This handshake demonstration enables students to think that the handshake between $\mathrm{A}$ and $\mathrm{B}$ is equal to the handshake between $\mathrm{B}$ and $\mathrm{A}$. The 1st round handshake was done by $\mathrm{A}$ to his friends $\mathrm{B}, \mathrm{C}$, and $\mathrm{D}$. Then 2nd round handshake from $\mathrm{B}$ to $\mathrm{C}$ and $\mathrm{D}$, here students were very easy to understand that $\mathrm{B}$ did not need to do the handshake again with $\mathrm{A}$ because the handshake had been done from A to B in the previous round. The last, 3rd handshake was done by $\mathrm{C}$ and D. All students tried to answer the given problem and could determine the number of handshakes of 4 students easily. Furthermore, to get more comprehensive understanding, the teacher provided additional activities in activities 2 and 3. 


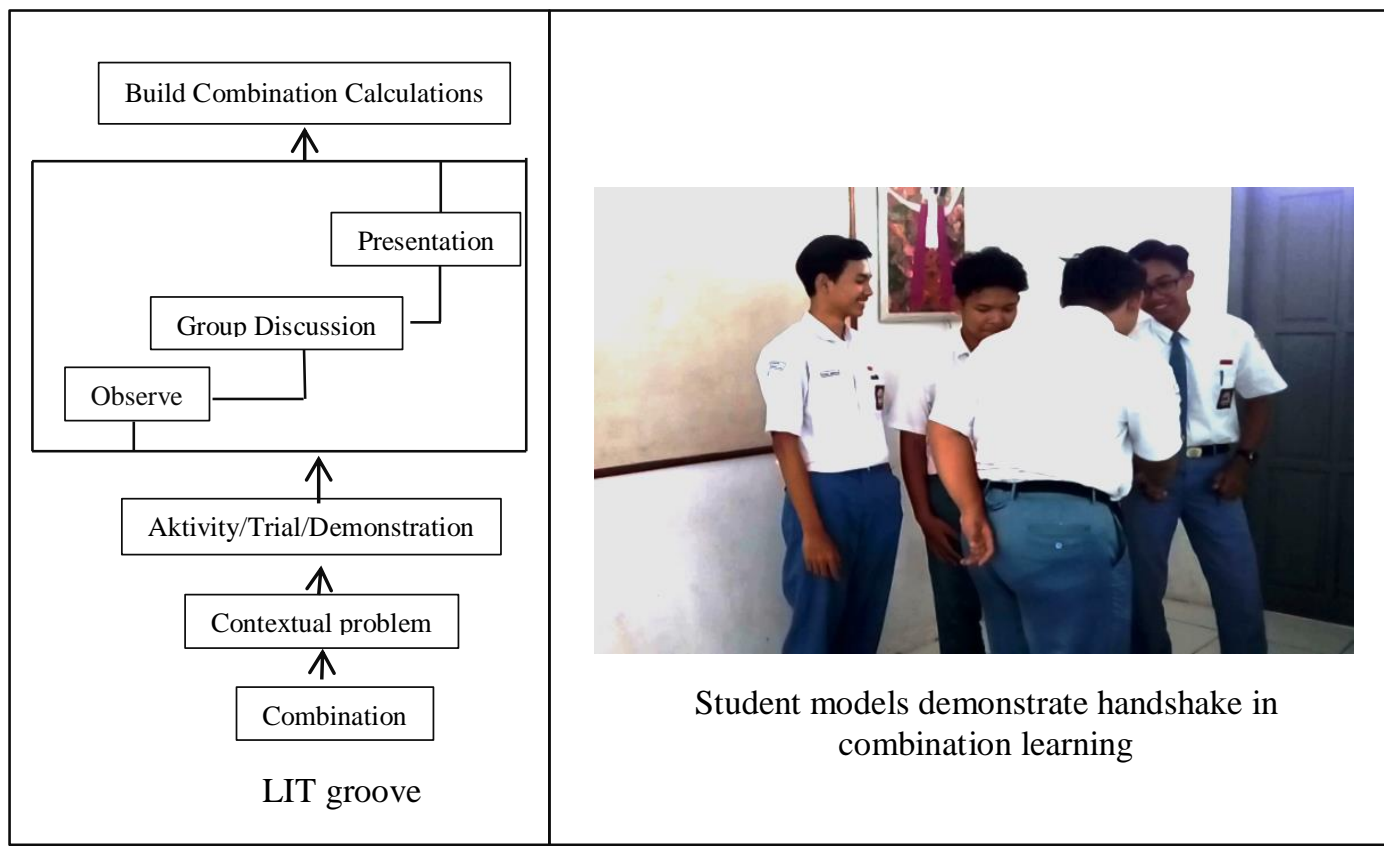

Figure 1. LIT groove and handshake demonstration on combination learning

\section{Activity 2}

In this activity the teacher asked students to determine the number of color mixtures formed from some colors provided. The problem in this activity was to lead students to find the formal mathematical formula of the combination.

This activity run well because students had got a concept from previous handshake activities. In addition, the problem of color mixtures could also be understood by students as a contextual problem and could be imagined by students easily. The LIT design on this combination material was composed from a simple one and led to a general mathematical solution. The given problem was mixing 2 colors of 3 colors, mixing 3 colors of 4 colors, mixing 3 colors from 5 colors, and mixing 2 colors out of 5 colors. The result of the number of color mixtures obtained by the students were represented in the relationship table among the number of colors mixtures $(r)$, the number of colors available $(n)$, and the number of formed colors mixtures. This table was made to facilitate students in vertical mathematization and find the formal mathematical formulas of combinations.

Figure 2 presents a table of results of student processes in finding formal mathematics from the concept of combination. This table is preceded by giving contextual problems so that students can find many ways manually. This is a vertical mathematization process where students are guided to find formal mathematics based on the pattern of problems given. 


\begin{tabular}{|c|c|c|c|c|c|c|}
\hline No. & $\mathbf{r}$ & $\mathbf{n}$ & $\begin{array}{c}\text { Banyak } \\
\text { cara }\end{array}$ & $\mathbf{r} !$ & $\mathbf{n} !$ & $\begin{array}{c}\text { Hubungan } r !, \mathrm{n} ! \text { dan } \\
\text { banyaknya cara }\end{array}$ \\
\hline a. & 2 & 3 & $\begin{array}{r}3 \\
\text { cara }\end{array}$ & $2 !=2 \times \ldots$ & $3 !=3 \times 2 \times 1.1$ & $\begin{aligned} 3 & =\frac{3 \times 2 \times 1}{2 \times 13 !} \\
& =\frac{3 !}{2 !}=\frac{3 !}{2 ! ! !}\end{aligned}$ \\
\hline b. & 2 & 4 & $\begin{array}{c}6 \\
\text { cara }\end{array}$ & $2 !=2 \times 1$ & $4 !=4 \times 3 \times 2 \times 1$ & $\begin{array}{c}6: \frac{4 \times 3 \times 2 \times 1}{(2 \times 1)(2)} \\
=\frac{4 !}{2 ! 2 !}\end{array}$ \\
\hline c. & 3 & 4 & $\begin{array}{c}4 \\
\text { cara }\end{array}$ & $3 !=3 \times 2 \times 1$ & $4 !=4 \times 3 \times 2 \times 1$ & $\begin{aligned} A & =\frac{4 \times 3 \times 2 \times 1}{3 \times 2 \times 1} \\
& =\frac{4 !}{3 !}=\frac{4 !}{3 ! 1 !}\end{aligned}$ \\
\hline d. & 2 & 5 & $\begin{array}{l}10 \\
\text { cara }\end{array}$ & $2 !=2 \times 1$ & $\begin{array}{c}5 !=5 \times 4 \times 3 \times 2 \\
\times 1\end{array}$ & $\begin{aligned} 10 & =\frac{5 \times 4 \times 3 \times 2 \times 1}{(2 \times 1)(3 \times 2 \times 1)} \\
& =\frac{5 !}{2 ! 3 !}=\end{aligned}$ \\
\hline e. & 3 & 5 & $\begin{array}{l}10 \\
\text { cara }\end{array}$ & $3 !=3 \times 2 \times 1$ & $\begin{array}{c}5 !=5 \times 4 \times 3 \times 2 \\
\times 1\end{array}$ & $\begin{aligned} 10 & =\frac{5 \times 4 \times 3 \times 2 \times 1}{(3 \times 2 \times 1)(2 \times 1)} \\
& =\frac{5 !}{2 ! 3 !}\end{aligned}$ \\
\hline f. & 4 & 5 & $\begin{array}{c}5 \\
\text { cara }\end{array}$ & $\begin{aligned} 4 != & 4 \times 3 \times 2 \\
& \times 1\end{aligned}$ & $\begin{aligned} & 5 != 5 \times 9 \times 3 \times 2 \\
& \times 1\end{aligned}$ & $\begin{aligned} 5 & =\frac{5 \times 9 \times 3 \times 2 \times 1}{9 \times 3 \times 2 \times 1} \\
& =\frac{5 !}{9 ! 1 !}\end{aligned}$ \\
\hline g. & $\mathbf{r}$ & $\mathrm{n}$ & $C_{r}^{n}$ & $\mathrm{r} !$ & n! & $c_{r}^{n} \frac{n !}{r !(n-r) !}$ \\
\hline
\end{tabular}

Figure 2. Vertical mathematization rocess of students in producing the formal mathematics of combinations

\section{Activity 3}

In this activity the teacher presented the material by giving daily life problem. This was to train students in solving problems related to everyday life, after this activity was completed, the teacher gave test. The one of questions of combination in the form of the story is given below:

In a parent meeting at a high school attended by 25 people. The parents shook hands with each other. What is the number of greetings that occur if there are two pairs of husband and wife who attend the meeting and they do not shake hands with their partner?.

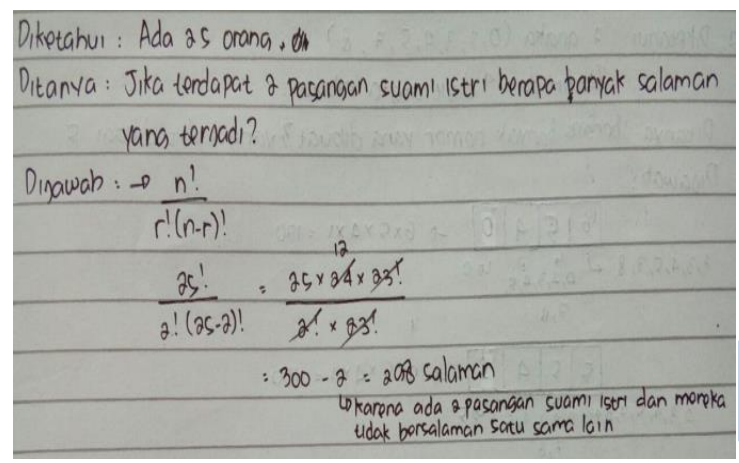

Translate in English:

Known : There are 25 people

Asked : if there were 2 pairs of husband and wife, how many handshakes happened?

Answer $: \frac{n !}{r !(n-r) !}=\frac{25 !}{2 ! 23 !}=300$

$300-2=298$ handshakes $\downarrow$

because there are 2 pairs of husband and wife who they do not shake hands with their partners

Figure 3. One of student's answers in accomplishing story question 
Figure 3 is an example of students' answers in accomplishing a story form question by using combination concept. Students could solve problems using formal mathematical formula combinations of $r$ elements of different $n$ elements obtained from previous activities.

\subsection{Retrospective Analysis}

The data analysis performed in this phase uses the initial HLT as a guideline and reference point in analyzing the entire data set collected during the teaching experiment. HLT is compared to the teaching and learning processes that occur in the classroom. The interpretive framework for understanding student learning process primarily is RME theory. The description of the analysis is not just about the examples that support the conjectures, but also the opposite. The conclusions of this analysis are used as the answers to the research questions. The main result is not primarily a successful design, but the reason of its works (Cobb et al., 2003; Gravemeijer \& Cobb, 2006).

Based on the results of activities in classroom learning activities, obtained LIT flow diagrams before and after learning in combination material, presented in Figure 4. In Figure 4 can see the changes in the steps in learning, shown in the steps in the red box. This is the result of research findings that students better understand the concept of combination if it is built based on the right LIT flow (after learning).

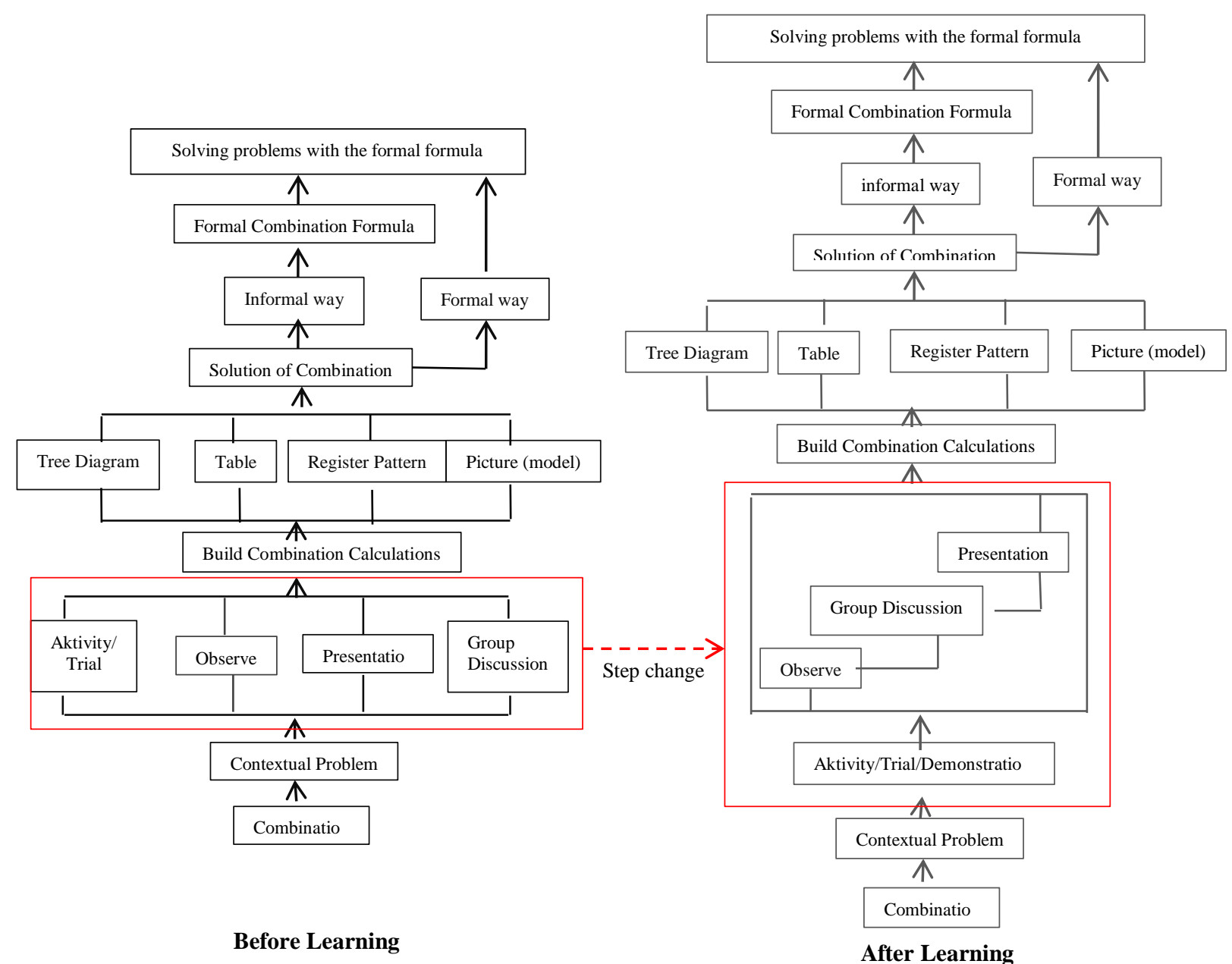

Figure 4. LIT Flow Chart in Combination Material 
By using the right LIT flow (Figure 4), the results of HLT analysis and teaching experiment, students are able to construct a combination of problematic situations, find combinations and its formula, calculate combinations of $r$ elements from different $n$ elements, solve problems in everyday life associated with combinations. Based on the students' work on the combination design of LIT, students are able to work on the activities and problem solving which reaches $76 \%$. Students are familiar with the learning process, the process of determining the formal mathematical form of the pattern / model created previously. The use of relationship table between $r$ !, $n$ ! and the number of ways obtained in this LIT combination design can help achieve the vertical mathematical process. Students are able to solve everyday problems by using the rules of multiplication or the sum of several combinations.

The results of the test completion of combination which is given after learning process showed that students of low ability category were $64 \%$, students of medium ability category were $70 \%$ and high ability category students were $80 \%$. The results of this achievement indicate that learning using a combination of UBA-LIT teaching materials can develop students' understanding of combination.

\section{CONCLUSION}

The idea of combining comes when students directly observe the handshake demonstration process to determine that the handshake of $\mathrm{A}$ with $\mathrm{B}$ is equal to the handshake of $\mathrm{B}$ with $\mathrm{A}$, this combination concept means that the $\mathrm{AB}$ sequence is equal to the BA sequence. The study also showed that students could remember what they had experienced but this did not mean that they could automatically transform their experience into abstract knowledge like the concept of combining calculations. Although the students admitted that the calculation of combinations in determining the color mixtures in which the sequence of $\mathrm{AB}=\mathrm{BA}$, but they still felt a common misconception when they were given the problem in the form of a story. This raises the need to improve the design by adding more focused activities to allow students to validate this misunderstanding. In addition, group activities are intended to solve problems in story form as an application of combination concept. This activity allows students to communicate the subject of math with their friends during the learning process. This suggests that learning processes not only occur within individuals, but also involve social interaction among them. This is in line with the notion of social norms and socio-mathematics proposed by Yackel \& Cobb (1996).

\section{REFERENCES}

Azhar, E. \& Kusumah, Y. S. (2011). Pengembangan Perangkat Pembelajaran Teori Peluang Berbasis RME Untuk Meningkatkan Pemahaman, Penalaran, dan Komunikasi Matematik Siswa SLTA. Prosiding Seminar Nasoinal Matematika dan Pendidikan Matematika 2011, Pendidikan Matematika FMIPA UNY, Yogyakarta, 3 Desember 2011, 213-222.

Ben-Hur, M. (2006). Concept-rich mathematics instruction: Building a strong foundation for reasoning and problem solving. Alexandria, VA: Association for Supervision and Curriculum Development. 
Busadee, N., \& Laosinchai, P. (2013). Authentic problems in high school probability lesson: Putting research into practice. Procedia-Social and Behavioral Sciences, 93, 2043-2047.

Cobb, P., Confrey, J., DiSessa, A., Lehrer, R., \& Schauble, L. (2003). Design experiments in educational research. Educational researcher, 32(1), 9-13.

Eizenberg, M. M., \& Zaslavsky, O. (2004). Students' verification strategies for combinatorial problems. Mathematical Thinking and learning, 6(1), 15-36.

Fischbein, H. (1975). The intuitive sources of probabilistic thinking in children (Vol. 85). Springer Science \& Business Media.

Fitria, N. L. (2013). Pengembangan Lembar Kerja Siswa (LKS) Materi Permutasi Dan Kombinasi Menggunakan Masalah Kontekstual. SKRIPSI Jurusan MatematikaFakultas MIPA UM.

Freudenthal, H. (1991). Revisiting Mathematics Education: China lectures. Kluwer Academic Publishers. Dordrecht, the Netherlands.

Garfield, J., \& Ahlgren, A. (1988). Difficulties in learning basic concepts in probability and statistics: Implications for research. Journal for research in Mathematics Education, 19(1), 44-63.

Gravemeijer, K. (1999). How emergent models may foster the constitution of formal mathematics. Mathematical thinking and learning, 1(2), 155-177.

Gravemeijer, K. (2004). Local instruction theories as means of support for teachers in reform mathematics education. Mathematical thinking and learning, 6(2), 105-128.

Gravemeijer, K., \& Cobb, P. (2006). Design research from a learning design perspective. In Educational design research (pp. 29-63). Routledge.

Herman, T. (2007). Pembelajaran berbasis masalah untuk meningkatkan kemampuan berpikir matematis tingkat tinggi siswa sekolah menengah pertama. Educationist, $1(1), 47-56$.

Meika, I., \& Suryadi, D. (2018). Students' errors in solving combinatorics problems observed from the characteristics of RME modeling. In Journal of Physics: Conference Series, 948(1), 012060.

Van de Walle, J. A. (2008). Matematika sekolah dasar dan menengah. Terjemahan Suyono). Jakarta: Penerbit Erlangga.

Yackel, E., \& Cobb, P. (1996). Sociomathematical norms, argumentation, and autonomy in mathematics. Journal for research in mathematics education, 458-477.

Yulianti, Y., Zulkardi, Z., \& Ilma, R. (2014). Pengembangan Perangkat Pembelajaran Peluang Berbasis Reciprocal Teaching Untuk Melatih Kemampuan Berpikir Kritis Siswa Kelas XI Smk Negeri 3 Lubuklinggau. Jurnal Pendidikan Matematika, 4(2). 